\title{
The Impact of Performance Management on Mission Statement and Operational Goal Setting
}

\author{
Fatemeh S. Shahmehr ${ }^{1}$, Narges Safari ${ }^{1}$, Mohammad Javad Jamshidi ${ }^{1} \&$ Noor-Mohammad Yaghoobi ${ }^{1}$ \\ ${ }^{1}$ Faculty of Entrepreneurship, University of Tehran, Tehran, Iran \\ Correspondence: Fatemeh S. Shahmehr, Faculty of Entrepreneurship, University of Tehran, Tehran, Iran. Tel: \\ 98-919-394-2362. E-mail: Shahmehr.f@gmail.com
}

Received: August 19, 2014

Accepted: September 15, $2014 \quad$ Online Published: October 22, 2014

doi:10.5539/ijbm.v9n11p189

URL: http://dx.doi.org/10.5539/ijbm.v9n11p189

\begin{abstract}
In the last 20 years tremendous changes have occurred in the two fields of performance appraisal and performance management. These changes can be observed both in managerial practices and academic researches. The terms performance appraisal and performance management are used interchangeably, but it can be realized that performance appraisal is about measuring performance in organization whereas the goal of performance management is making use of the results of appraisal in order to control and manage performance. Performance management is a strategic and integrated process which provides sustainable success for organizations through developing individual and group capabilities and matching individual performance with organizational objectives. This article reviews the mission statement, strategiesand operational goal setting role in performance management in Hospitals throughout a combined approach of quantitative and qualitative research. Statistical and contextual analysis helps us to examine the priority of each factor. The results shown that mission statement, HR strategies and goal setting have a critical role in describing performance management strategies.
\end{abstract}

Keywords: performance management, mission statement, operational goal setting, hospital

\section{Introduction}

Scholars define management as the process of the effective and efficient use of human and resources via planning, organization, guidance and control in order to achieve the organization objectives and objectives. What is perceived from this definition and the similar definitions is the fact that productivity, the increase of efficiency and effectiveness are of the important issues which are the center of management activities (Chong, Chan, Ooi, \& Sim, 2011; Kull \& Wacker, 2010; Mwita, 2000). Human resource is one of the most important resources in organization. Profitability and efficiency, survival and stability of every organization depend on the ability, capacity, performance and qualification of its employees and experts (Gruman \& Saks, 2011; Huselid \& Becker, 2010; Mills \& Smith, 2011; Noruzy, Dalfard, Azhdari, Nazari-Shirkouhi, \& Rezazadeh, 2013).

Organizations provide a strategy for achieving this enterprise to improve the situation of their employees (Kehoe \& Wright, 2013) and increase the awareness of them (Lengnick-Hall, Beck, \& Lengnick-Hall, 2011) as well as establish positive changes in the way that they have planned to go (Bloom \& Reenen, 2011), since the skilled employees are able to convert knowledge into products and services and to bring profitability for the organization (Aubry \& Hobbs, 2011; CHUANG \& Liao, 2010; Walker, Damanpour, \& Devece, 2010). Performance Management (PM) is an approach which helps organization to investigate its capabilities in environmental complexities (López-Nicolás \& Meroño-Cerdán, 2011; Mwita, 2000). PM is an integrating strategic process which provides sustained success of the organization by improving the individual performance (García-Morales, Jiménez-Barrionuevo, \& Gutiérrez-Gutiérrez, 2012). PM is known as a strategic phenomenon relating to organizational capabilities to earn the long-term aims and mission which the organization has been looking for (Guest, 2011; Mossholder, Richardson, \& Settoon, 2011) and has in turn built up from two point of views: first, vertical integration in which employees apply their skills in groups and teams to assist each other for reaching to the goals (Avey, Reichard, Luthans, \& Mhatre, 2011; Ndofor, Sirmon, \& He, 2011). Second, horizontal integration in which organization relies on the Human Resources (HR) capabilities individually and reward systems for accessing a coherent approach in employees development management (Fasanghari, Roudsari, \& Chaharsooghi, 2008). The research by Mills and Smith (2011) shows that the majority of organizations have a long path to establish a system of PM because this system is not only to evaluate the 
organizational performance, but enables managers to follow up the targeted mission. In other words, PM is to establish a common vision for each single employee and derives them through the right way (Jamil, Yusof, Said, \& Osman, 2010).

Hospitals can be indicated as organizations that rely on their own structures, mission and special services. Considering the unique characteristics of these organizations, the main aim of hospitals is not the maximization of organizational value but the best realization of the mission. However, these organizations must be managed and supervised similar to other organizations to make income and value for the whole organization and other stakeholders. The compounded and integrated organizational mission and PM in one side and the collaboration of performance evaluation criteria with operational objectives and strategies on the other side, remain this question: How does PM affects organizational mission, human resource strategies and operational goal setting? This paper is aimed to respond this question to help hospital in creating a welcoming atmosphere to new ideas.

Organizations need to continuously be updated in complex environmental changes (Barney, Ketchen, \& Wright, 2011). The requests specific reformations in individual and organizational performance that is the key of success in the competition. Factors such as rapid environmental changes, chronic deficit in budget, minimization and reformation, social pressures for greater accountability of organizations for their performance emphasize the need for further studies on PM. The literature illustrates that PM begins with the definition and interpretation of missions, strategies and organizational objectives in relation to the goals of employees' individual performance along with performance standards (Bernardin \& Wiatrowski, 2013). This important fact causes that organizations use this system to understand the rate of the fulfillment of organizational objectives (Jamil et al., 2010; Moynihan \& Lavertu, 2012).

However, organizations have paid more attention to their human resources in recent years as they have always been seeking methods for improving performance and for upgrading job conditions (Evans \& Lindsay, 2012; Williams Jr, Morrell, \& Mullane, 2014). It is claimed that attentions to the performance of human resources can be summarized in improvement of organizational performance (Moynihan \& Lavertu, 2012). PM is a process in which the relation and coordination between organization performance and the performance of human resource would be established. In the other words, PM refers to "an integrated set of policies and actions in which the emphasis on individual performance would lead to achieving organizational objectives (Shane, 2010).

\section{Literature Review}

Mwita (2000) believes that the first step in the process of PM is to design the mission statement of organization. This is a brief definition of the organization objectives in answering which should be done and what should be obtained? According to existential philosophy, society expectations and organization values are included in the framework of mission statement (Lyng, 2012). The mission statement or the organization vision is a document which replies questions such as what is our goal, why do we exist, what do we want to do? (O'Donohue \& Nelson, 2014).

In recent years, the organizations have focused more on missions that include "greater motivation of employees" and "greater allocation of human resources" more than other missions that might be even associated with financial statements (Ulrich, 2013). The mission statement as a fundamental instrument, establishes a public aim for the organization, defines the domain of activities and operations in the organization, determines performance standards for people, helps the establishment of correct interpretation of tasks, objectives and strategies, tries to establish common values among the organization members and establishes a common motto for allocating human resources of organization by inspiring and motivating them (Bernardin \& Wiatrowski, 2013; Evans \& Lindsay, 2012; Moynihan \& Lavertu, 2012; Williams Jr et al., 2014). Rodney and Hazlett (2005) point out that the mission statement establishes common objectives in which employees are identified. The findings of several studies show that the mission statement might even lead to change in individual performance (Khoury \& Analoui, 2004; Nickson, 2013). Ulrich (2013) investigated the relationship between mission statement, organization performance and individual performance. His research came to this conclusion the three are related to each other. These findings can be found in some other studies as well. Accordingly, the first hypothesis can be recognized as follows:

H1: There is a positive and significant relationship between PM and organizational mission.

Organizations establish mission statement to achieve their special objectives which derive all employees towards final goals (desirable condition) and its achievement (Effectiveness). Therefore, designing objectives and the method of achieving those objectives are very important for designing the mission statement (Bernardin $\&$ Wiatrowski, 2013; Schunk \& Zimmerman, 2012). The essential assumption of goal setting theory is to manage and regulate individual values in organizational context by considering the fact that organization is a whole 
(Nickson, 2013). According to Jamil, et al (2010), the certain and challenging objectives might lead to an improvement of performance rather than ambiguous and aimless objectives for $\% 90$ of cases. Aubry and Hobbs (2011) state that goal setting accounts for \%40 in performance improvement. Generally, goal setting and the process of designing human resource strategies can have a significant impact on PM. Organizations apply individual performance standards, the continuously supervision of performance activities to determine objectives and strategies for reaching their mission statement (Cameron, 2012; Schunk \& Zimmerman, 2012).

Additionally, Mwita (2000) contends that PM can be influenced by operational objectives. These objectives determine the policy of every section in an organization. Practical programs of performing organizational strategies need the optimized allocation of human and non-human resources and they commit themselves to main duties and responsibilities based on their qualifications and merits (Brennan \& Elkins, 2013). Therefore, the second and third hypotheses can be defined as follows:

$\mathrm{H} 2$ : There is a positive and significant relationship between PM and human resources strategies.

H3: There is a positive and significant relationship between PM and operational goal setting.

\section{Research Method}

Considering the fact that the present research is going to determine the role of mission statement, strategies of human resources and operational goal setting in PM, the statistical population should be acquainted with macro strategies of the organization in the prospective document and have the minimum level of experience (Kumar \& Phrommathed, 2005). Therefore, regarding the specialized research questionnaire, the statistical population of the research includes all consultants, managers and administrators of the Milad hospital in Tehran. Therefore, 30 participants were selected randomly from the statistical population. Then, they were required to respond a 4-section questionnaire of PM, as a pilot research. The size of dependent attribute variance of PM (variance of total questions) was calculated: $\mathrm{S}^{2}=11.49$

According to the calculated formulas of estimating the simple random sample size without substitution, we have:

$$
n .=\frac{Z^{2} S^{2}}{d^{2}} \quad \text { and } \quad n=\frac{n .}{1+\frac{n \cdot}{N}}
$$

$\mathrm{N}$ : The size of understudied universe; $\mathrm{n} .:$ sample size; $\mathrm{S}^{2}$ : variance of dependent attribute; $\mathrm{Z}$ : the bound of the error 5 percent level (1/96); d: the bound of the error of tolerable attribute

Therefore:

$$
n .=\frac{(1.96)^{2}(11.49)}{(.375)^{2}}=313 \quad n=\frac{313}{1+\frac{313}{400}}=175
$$

This sample had 220 participants, selected from various departments of the Milad hospital, including 6 top management, 24 section managers and the rest were administrators. Then, 220 questionnaires were distributed among them by the presence of the researcher. Before distributing the questionnaire, we contacted all participants over the phone to make sure they would like to take part of research. We, then, asked them some questions to ensure they are qualified enough to become interviewed. However, only 179 questionnaires were returned. The rate of returning questionnaires was 81 percent which signifies the excellent cooperation of managers and administrators in the research. In addition, in-depth interviews were conducted for 25 of administrators to provide the researchers with new ideas and contributions, selected from the employees with the following characteristics:

- The managers who have a long-time experience in the hospital.

- The consultants who have been working for the hospital since 5 years ago.

The interviews helped us to investigate the reliability of the questionnaire. Furthermore, interviews implicitly included new insights in terms of policy-making and decision-making in hospitals where managing employees and dealing with patients push managers toward using encouragement systems.

Data analysis has been derived by Structural Equation Modeling (Path Analysis) in which the conceptual model of the research was evaluated by LISREL 8.5 and SPSS 18. For determining reliability of the study, the Cronbach's Alpha method was used. SEM is a qualitative method for evaluating conceptual models which deal with casual assumptions. It also allows testing hypotheses by considering the fact the hypotheses must be 
examined simultaneously. Inthis paper, we used SEM to determine how the model fits the data.

Table 1 . The reliability of the research

\begin{tabular}{ll}
\hline Questions & Cronbach's Alpha \\
\hline Independent Variable (PM) & 0.88 \\
Dependent Variables & 0.93 \\
\hline
\end{tabular}

The content validity of this questionnaire was justified by guide two professors and 5 associate professors and also initial distribution of questionnaire among a number of experts and scholars in University of Tehran, Iran, as well as considering their corrective comments.

\section{Findings}

The data obtained from the demographic variable shows that $34 \%$ of participants were females and $66 \%$ was males. $34 \%$ of participants were Bachelors, $42 \%$ were Masters, $18 \% \mathrm{PhD}$ holders and $5 \%$ Post-Doctoral degree. $15 \%$ of the participants have been working in in this area less than 5 years, $17 \%$ between 5 and 15 years, $29 \%$ between 16 and 25 years, and 39\% over 25 years.

In terms of interviews and observations, this research is carried out by Shannon Entropy method. This method is adopted from the theory of systems and is a new method for processing data (Lin, 1991). Entropy in information theory is an index for measuring uncertainty which can be stated by a probability distribution. This uncertainty is known as follows (Zellner \& Highfield, 1988):

$$
E \cong S\left\{P_{1}, P_{2}, \ldots . ., P_{n}\right\}=-k \sum_{i=1}^{m}\left[P_{i} L_{n} P_{i}\right] 0 \leq E \leq 1
$$

In which, $\mathrm{k}$ is a positive stable amount in order to make $\mathrm{E}$ permanently positive.

The mathematical equation is debated by this assumption that a message from $m$ points of view, classified in $n$ category. The Shannon Entropy method is needed for explaining algorithm in which the message is counted according to categories in tune with each responder through frequency matrix at first. After extracting frequency tables, the frequency matrix would be normalized or standardized. To do so, the following equation will be used:

$$
P_{i j}=\frac{F_{i j}}{\sum_{i=1}^{m} F_{i j}}(i=1,2, \ldots ., m), j=(1,2, \ldots ., n)
$$

In the second stage, the information at each category can be calculated by the following equation:

$$
E_{i}=-k \sum_{i=1}^{m}\left[P_{i j} L_{n} P_{i j}\right], j=(1,2, \ldots ., n)
$$

In which

$$
k=\frac{1}{L_{n} m}
$$

Then, the important factor of each category would be calculated by information obtained from a category. Each category which has the greatest value, accounts for the most important factor $(\mathrm{Wj})$ :

$$
W_{J}=\frac{E_{J}}{\sum_{J=1}^{n} E_{j}} j=(1,2, \ldots, n)
$$

$\mathrm{Wj}$ is an index which signifies important factor of each $\mathrm{j}$ category in a message with respect to the total number of participants. However, categories resulted from the messages, can be classified in w. A more accurate description of the method of processing and analyzing information obtained from interviews with experts in Milad hospital is presented in Table 1. As noticed, this research includes 25 interviews with managers and administrators of Milad hospital. The questions identified the importance of each factors of mission statement of Milad hospital, human resources strategies and extracted programs from the prospective document, operational objectives of the units in the PM of Milad hospital. 
The content of carried out interviews based on the seven categories are as depicted in the table 2 .

Table 2. The determined categories of the qualitative research

\begin{tabular}{|c|c|c|c|c|c|c|}
\hline $\mathrm{X}_{1}$ & $\mathrm{X}_{2}$ & $\mathrm{X}_{3}$ & $\mathrm{X}_{4}$ & $\mathrm{X}_{5}$ & $\mathrm{X}_{6}$ & $\mathrm{X}_{7}$ \\
\hline $\begin{array}{l}\text { Prospective } \\
\text { (Mission } \\
\text { Statement) }\end{array}$ & $\begin{array}{l}\text { Strategies } \\
\text { \&Programs }\end{array}$ & $\begin{array}{l}\text { Operational } \\
\text { Programs }\end{array}$ & $\begin{array}{l}\text { Environmental } \\
\text { Factors }\end{array}$ & $\begin{array}{l}\text { Managers' Individual } \\
\text { Characteristics }\end{array}$ & $\begin{array}{l}\text { informational } \\
\text { systems } \\
\text { organization }\end{array}$ & $\begin{array}{l}\text { Managers' } \\
\text { preferences }\end{array}$ \\
\hline
\end{tabular}

The amount of the uncertainty resulted from each category is calculated after extracting frequency relating to every category and their normalization (table 3 ).

Table 3. The rate of uncertainty of each category

\begin{tabular}{|c|c|c|c|c|c|c|c|}
\hline Category & $\mathrm{X}_{1}$ & $X_{2}$ & $X_{3}$ & $\mathrm{X}_{4}$ & $\mathrm{X}_{5}$ & $\mathrm{X}_{6}$ & $\mathrm{X}_{7}$ \\
\hline Uncertainty & $0 / 947$ & $0 / 987$ & $0 / 991$ & $0 / 953$ & $0 / 986$ & $0 / 964$ & $0 / 986$ \\
\hline
\end{tabular}

Then, the important factor of every category is calculated. Table 4 shows these factors for each category.

Table 4. Factors for each category

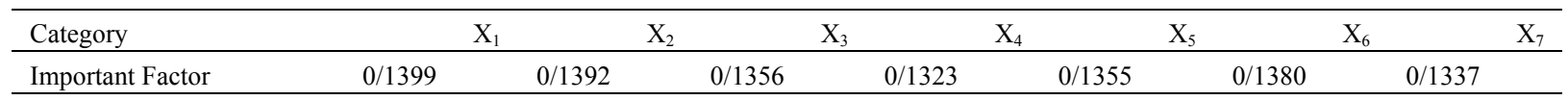

It is considered that the effective variables on PM and their priority can be stated as the table 5. Five independent variables have directly impact on PM in Milad hospital.

Table 5. Coefficients of each category in PM

\begin{tabular}{llllllll}
\hline Category & Managers' & informational & Individual & Environmental & Operational & Strategies & $\begin{array}{l}\text { Mission } \\
\text { \&Programs }\end{array}$ \\
& preferences & systems & Characteristics & Factors & Objectives & stemt \\
\hline Priority & sixth & first & seventh & third & second & fifth & fourth \\
\hline
\end{tabular}

In the next step, the priority of every variable is determined by Delphi method to ensure the outcomes of interview and alignment in final results. The results of using the Delphi method are shown in Table 6.

Table 6. The extracted variables from Delphi analysis

\begin{tabular}{rrrrrrr}
\hline $\begin{array}{r}\text { Environmental } \\
\text { Factors }\end{array}$ & $\begin{array}{r}\text { Operational } \\
\text { Programs }\end{array}$ & $\begin{array}{r}\text { Strategies } \\
\text { \&Programs }\end{array}$ & Managers' & $\begin{array}{r}\text { Individual } \\
\text { Characteristics }\end{array}$ & $\begin{array}{r}\text { Mission } \\
\text { Statement of } \\
\text { organization }\end{array}$ & $\begin{array}{r}\text { Variable } \\
\text { fourth }\end{array}$ \\
fifth & third & first & & second & Priority \\
\hline
\end{tabular}

\subsection{Testing Hypotheses}

Structural equation modeling (SEM) was used to determine correlations between variables of the proposed model and confirmed proposed model. In other words, since different models can be proposed based on hypotheses, structural equation modeling using a series of key indicators of credit is used to fit the proposed model Therefore, LISREL software was used to fit the proposed model and test research hypotheses and SPSS software was used to investigate regression analysis hypotheses. Two methods are considered for data analysis and for showing the validity of the research hypotheses.

\subsubsection{Goodness of Fit Tests}

Although different types of tests which generally called fitness index are continuously being compared, developed and evolved but still there is no general agreement on any optimal test. The result is that different articles, have presented different indices and even the famous SEM programs writings such as EQS LISREL 
software's and Amos lose too many of fitness indices. After specifying the model, several ways to estimate the goodness of fit of the model is used. To confirm the model three to five indices are sufficient. The goodness of fit of a statistical model describes how well it fits a set of observations. Measures of goodness of fit typically summarize the discrepancy between observed values and the values expected under the model in question. Such measures can be used in statistical hypothesis testing. Generally, in this study to assess the goodness of fit of the entire model measures such as $\chi^{2}$ / df, RMR, GFI, AGFI, RMSEA, NFI, NNFI, CFI has been used.Numbers of each of these indices has come in the table 7.

Table 7. Goodness of fit tests for research hypothesis

\begin{tabular}{|c|c|c|c|c|c|c|c|c|}
\hline & & & Root Mean & Goodness & Adjusted & & & omnarative \\
\hline index & $\begin{array}{l}\chi^{2} \\
/ \mathbf{d f}\end{array}$ & $\begin{array}{l}\text { Square Error of } \\
\text { Approximation }\end{array}$ & $\begin{array}{l}\text { Square } \\
\text { Residual } \\
\text { (RMR) }\end{array}$ & $\begin{array}{ll}\text { of } & \text { Fit } \\
\text { Index } & \\
\text { (GFI) } & \end{array}$ & \begin{tabular}{l}
\multicolumn{2}{l}{ Goodness } \\
of $\quad$ Fit \\
Index
\end{tabular} & $\begin{array}{l}\text { Fit Index } \\
\text { (NFI) }\end{array}$ & $\begin{array}{l}\text { Non-Normed } \\
\text { Fit Index }\end{array}$ & $\begin{array}{ll}\text { Fit Index } \\
\text { (CFI) }\end{array}$ \\
\hline $\begin{array}{l}\text { Conceptual } \\
\text { model }\end{array}$ & 1.48 & 0.063 & 0.041 & 0.94 & 0.94 & 0.92 & 0.90 & 0.96 \\
\hline \multirow{2}{*}{ reference } & $<3$ & $<0.100$ & $<0.050$ & $<0.90$ & $<0.90$ & $<0.90$ & $<0.90$ & $<0.90$ \\
\hline & \multicolumn{8}{|c|}{ Hair, et al. (2006); Tomer, A., Pugesek , (2003); Joreskog and Sorbom, (1996) } \\
\hline $\begin{array}{l}\text { Global } \\
\text { model fit? }\end{array}$ & good & Very good & Very good & Very good & Very good & good & Very good & Very good \\
\hline
\end{tabular}

Diagram 1 also shows significance and resulted parameters (t-Value) and Diagram 2 shows structural model of the study for confirming from hypotheses test. Significance value of the first and second hypotheses is placed out of $(-1.98,1.98)$ interval, therefore, formed relation is out of the null hypothesis and indicates the ratification of these hypotheses of the research. According to results of these two models (relation is based on standard estimation of 0.84 and 0.76 and is based on significance equal to 9.15 and 7.41 respectively). Hence, first and second hypothesis confirmed. Significance value of the third hypothesis is placed within $(-1.98,1.98)$ interval, therefore, formed relation is located within the null hypothesis and indicates the rejection of the third hypothesis of the study. According to results of these two models (relation is based on standard estimation of 0.23 and is based on significance equal to 1.66). Thus, third hypothesis rejected.

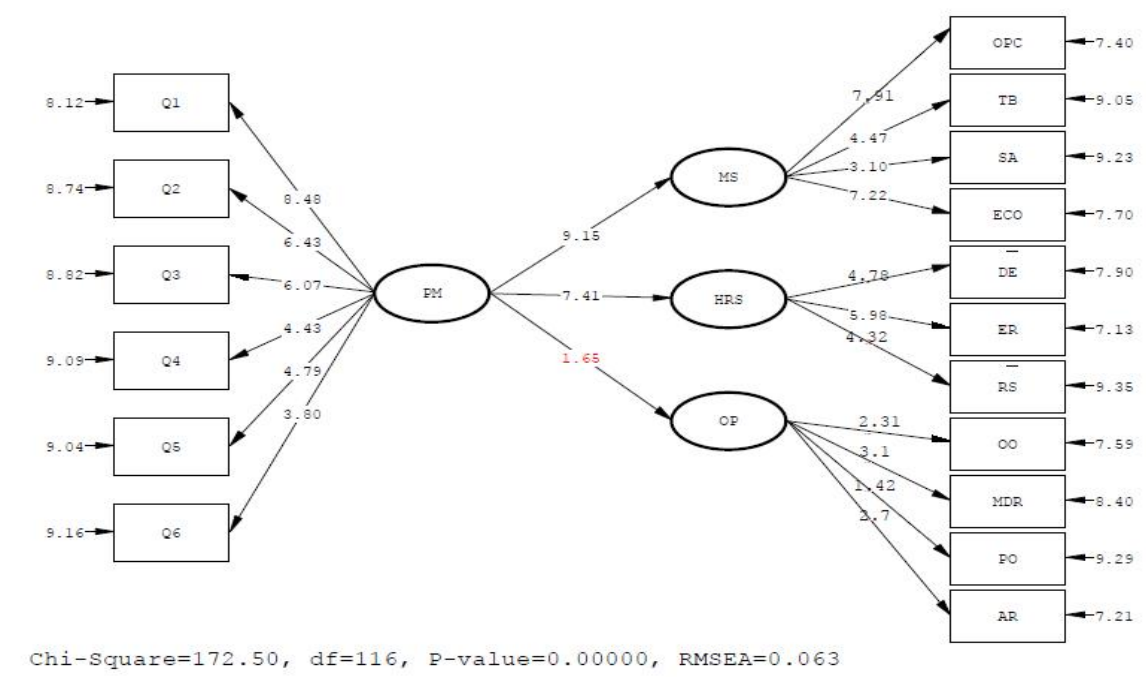

Figure 1. Structural model of study for confirming hypotheses in t-Value state 


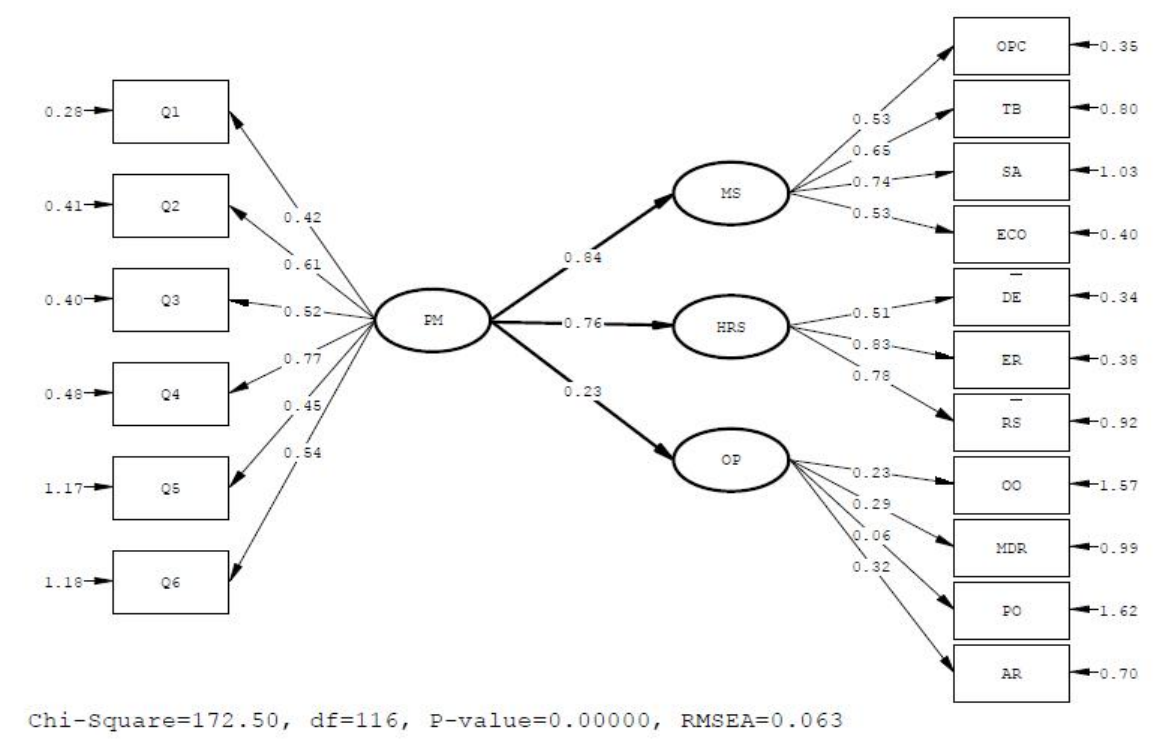

Figure 2. Structural model of study for confirming hypotheses in Standard estimates state

Based on analysis done using path analysis, results of testing hypotheses of the study can be seen in table 8 . Standard estimation test and significance values in confirming or rejecting considered hypothesizes (significance of hypotheses) have been used.

Table 8. Results of testing the hypotheses of the study using path analysis

\begin{tabular}{lllccc}
\hline Hypotheses of the study & & \multicolumn{1}{c}{ Path } & $\begin{array}{c}\text { Standardized } \\
\text { coefficient }\end{array}$ & $\begin{array}{c}\text { The Significance of } \\
\text { Values }\end{array}$ & $\begin{array}{c}\text { Testing of } \\
\text { Hypotheses }\end{array}$ \\
\hline First hypothesis & PM & Mission Statement & 0.84 & 9.15 & Confirmed \\
Second hypothesis & PM & HR strategies & 0.76 & 7.41 & Confirmed \\
Third hypothesis & PM & Operational goal setting & 0.23 & 1.65 & Rejected \\
\hline
\end{tabular}

\section{Discussion and Conclusion}

The research is organized to investigate the results of the qualitative analysis of managers and administrators who have been working in Milad hospital and the outcomes of testing statistical hypotheses along with the researcher's observations. To do so, the paper emphasizes the role of PM in successful goals of organization. Results indicate that PM positively relates to Mission Statement and HR strategies. As stated in the relevant studies (Chong et al., 2011; Jamil et al., 2010; Kull \& Wacker, 2010; Moynihan \& Lavertu, 2012; Mwita, 2000), PM has directly positive impact on mission statement and human resource strategies. However, some other researchers imply that mission statement itself might relate to HR strategies (Bernardin \& Wiatrowski, 2013; Schunk \& Zimmerman, 2012). Furthermore, the research points out that mission statement, human resources strategies and operational goal setting can be positively affected by PM. Regarding the nature of this organization and its dominated management type, it can be concluded that all efforts of managers and administrators are to derive organization toward aligning human resources with organizational mission. Therefore, the success of organization can be based on an effective performance resulted in collaboration between managers and employees.

Considering the high importance of organizational mission statement in PM process, this statement should be understood by employees and managers an appropriate way to assess organizational performances. However, the managers and employees must follow joint values such as training methods, service improvement, the responsibility of tasks, enhancement of productivity and decision-making for more concentration on products. PM in hospitals should concentrate on main components such as the role of people in promoting participation culture and reasoning people's interest in the investments. Moreover, reviving and expansion of endowment culture and preserving the endowments should be focused in designing, performing and supervising operational 
programs. Thus, it is suggested that some sessions with employees should be held every year in order to make them understand of objectives of each organizational section as well as evaluating their performance based on their rate of achieving operational objectives (Bernardin \& Wiatrowski, 2013; Schunk \& Zimmerman, 2012).

\section{References}

Aubry, M., \& Hobbs, B. (2011). A fresh look at the contribution of project management to organizational performance. Project Management Journal, 42(1), 3-16. http://dx.doi.org/10.1002/pmj.20213

Avey, J. B., Reichard, R. J., Luthans, F., \& Mhatre, K. H. (2011). Meta-analysis of the impact of positive psychological capital on employee attitudes, behaviors, and performance. Human Resource Development Quarterly, 22(2), 127-152. http://dx.doi.org/10.1002/hrdq.20070

Barney, J. B., Ketchen, D. J., \& Wright, M. (2011). The future of resource-based theory revitalization or decline? Journal of Management, 37(5), 1299-1315. http://dx.doi.org/10.1177/0149206310391805

Bernardin, H. J., \& Wiatrowski, M. (2013). Performance appraisal. Psychology and Policing, 257

Bloom, N., \& Reenen, J. V. (2011). Human resource management and productivity. Handbook of labor economics, 4, 1697-1767. http://dx.doi.org/10.1016/S0169-7218(11)02417-8

Brennan, B., \& Elkins, M. R. (2013). Goal setting, problem solving and feedback improve short-term adherence to physical activity in people with stable heart failure. British Journal of Sports Medicine, bjsports-2013-092956. http://dx.doi.org/10.1136/bjsports-2013-092956

Cameron, K. (2012). Positive leadership: Strategies for extraordinary performance. Berrett-Koehler Publishers.

Chong, A. Y., Chan, F. T., Ooi, K. B., \& Sim, J. J. (2011). Can Malaysian firms improve organizational/innovation performance via SCM? Industrial Management \& Data Systems, 111(3), 410-431. http://dx.doi.org/10.1108/02635571111118288

CHUANG, C. H., \& Liao, H. (2010). Strategic human resource management in service context: Taking care of business by taking care of employees and customers. Personnel Psychology, 63(1), 153-196. http://dx.doi.org/10.1111/j.1744-6570.2009.01165.x

Evans, J., \& Lindsay, W. (2012). Managing for quality and performance excellence. Cengage Learning.

Fasanghari, M., Roudsari, F. H., \& Chaharsooghi, S. K. (2008). Assessing the Impact of Information Technology on Supply Chain Management. World Applied Sciences Journal, 4(1), 87-93. http://dx.doi.org/10.1109/ISECS.2008.208

García-Morales, V. J., Jiménez-Barrionuevo, M. M., \& Gutiérrez-Gutiérrez, L. (2012). Transformational leadership influence on organizational performance through organizational learning and innovation. Journal of Business Research, 65(7), 1040-1050. http://dx.doi.org/10.1016/j.jbusres.2011.03.005

Gruman, J. A., \& Saks, A. M. (2011). Performance management and employee engagement. Human Resource Management Review, 21(2), 123-136. http://dx.doi.org/10.1016/j.hrmr.2010.09.004

Guest, D. E. (2011). Human resource management and performance: still searching for some answers. Human Resource Management Journal, 21(1), 3-13. http://dx.doi.org/10.1111/j.1748-8583.2010.00164.x

Huselid, M. A., \& Becker, B. E. (2010). Bridging micro and macro domains: Workforce differentiation and strategic human resource management. Journal of Management. http://dx.doi.org/10.1177/0149206310373400

Jamil, M. C., Yusof, N. A., Said, B., \& Osman, Z. (2010). Organizational culture and performance of resort operators of a lake-based tourism area in Malaysia. World Applied Sciences Journal, 10(5), 597-606. http://dx.doi.org/10.3844/ajassp.2012.417.424

Kehoe, R. R., \& Wright, P. M. (2013). The impact of high-performance human resource practices on employees' attitudes and behaviors. Journal of Management, 39(2), 366-391. http://dx.doi.org/10.1177/0149206310365901

Khoury, G. C., \& Analoui, F. (2004). Innovative management model for performance appraisal: the case of the Palestinian public universities. Management Research News, 27(1/2), 56-73. http://dx.doi.org/10.1108/01409170410784356

Kull, T. J., \& Wacker, J. G. (2010). Quality management effectiveness in Asia: The influence of culture. Journal of Operations Management, 28(3), 223-239. http://dx.doi.org/10.1016/j.jom.2009.11.003 
Kumar, S., \& Phrommathed, P. (2005). Research methodology. Springer US.

Lengnick-Hall, C. A., Beck, T. E., \& Lengnick-Hall, M. L. (2011). Developing a capacity for organizational resilience through strategic human resource management. Human Resource Management Review, 21(3), 243-255. http://dx.doi.org/10.1016/j.hrmr.2010.07.001

Lin, J. (1991). Divergence measures based on the Shannon entropy. Information Theory, IEEE Transactions on, 37(1), 145-151. http://dx.doi.org/10.1109/18.61115

López-Nicolás, C., \& Meroño-Cerdán, Á. L. (2011). Strategic knowledge management, innovation and performance. International Journal of Information Management, 31(6), 502-509. http://dx.doi.org/10.1016/j.ijinfomgt.2011.02.003

Lyng, S. (2012). Existential transcendence in late modernity: edgework and hermeneutic reflexivity. Human Studies, 35(3), 401-414. http://dx.doi.org/10.1007/s10746-012-9242-0

McAdam, R., Hazlett, S. A., \& Casey, C. (2005). Performance management in the UK public sector: addressing multiple stakeholder complexity. International Journal of Public Sector Management, 18(3), 256-273. http://dx.doi.org/10.1108/09513550510591542

Mills, A. M., \& Smith, T. A. (2011). Knowledge management and organizational performance: a decomposed view. Journal of Knowledge Management, 15(1), 156-171. http://dx.doi.org/ 10.1108/13673271111108756

Mossholder, K. W., Richardson, H. A., \& Settoon, R. P. (2011). Human resource systems and helping in organizations: A relational perspective. Academy of Management Review, 36(1), 33-52. http://dx.doi.org/10.5465/AMR.2011.55662500

Moynihan, D. P., \& Lavertu, S. (2012). Does involvement in performance management routines encourage performance information use? Evaluating GPRA and PART. Public Administration Review, 72(4), 592-602. http://dx.doi.org/ 10.1111/j.1540-6210.2011.02539.x

Mwita, J. I. (2000). Performance management model: a systems-based approach to public service quality. International Journal of Public Sector Management, 13(1), 19-37. http://dx.doi.org/10.1108/09513550010334461

Ndofor, H. A., Sirmon, D. G., \& He, X. (2011). Firm resources, competitive actions and performance: investigating a mediated model with evidence from the in-vitro diagnostics industry. Strategic Management Journal, 32(6), 640-657. http://dx.doi.org/ 10.1002/smj.901

Nickson, D. (2013). Human Resource Management for Hospitality, Tourism and Events. Routledge.

Noruzy, A., Dalfard, V. M., Azhdari, B., Nazari-Shirkouhi, S., \& Rezazadeh, A. (2013). Relations between transformational leadership, organizational learning, knowledge management, organizational innovation, and organizational performance: an empirical investigation of manufacturing firms. The International Journal of Advanced Manufacturing Technology, 64(5-8), 1073-1085. http://dx.doi.org/10.1007/s00170-012-4038-y

O'Donohue, W., \& Nelson, L. (2014). Alienation: an old concept with contemporary relevance for human resource management. International Journal of Organizational Analysis, 22(3), 301-316. http://dx.doi.org/10.1108/IJOA-01-2012-0541

Schunk, D. H., \& Zimmerman, B. J. (2012). Motivation and self-regulated learning: Theory, research, and applications. Routledge.

Shane, J. M. (2010). Performance management in police agencies: a conceptual framework. Policing: An International Journal of Police Strategies \& Management, 33(1), 6-29. http://dx.doi.org/10.1108/13639511011020575

Ulrich, D. (2013). Human resource champions: The next agenda for adding value and delivering results. Harvard Business Press.

Walker, R. M., Damanpour, F., \& Devece, C. A. (2010). Management innovation and organizational performance: the mediating effect of performance management. Journal of Public Administration Research and Theory, 43. http://dx.doi.org/ 10.1093/jopart/muq043

Williams Jr, R. I., Morrell, D. L., \& Mullane, J. V. (2014). Reinvigorating the mission statement through top management commitment. Management Decision, 52(3), 2. http://dx.doi.org/ 10.1108/MD-10-2012-0736

Zellner, A., \& Highfield, R. A. (1988). Calculation of maximum entropy distributions and approximation of 
marginalposterior distributions. Journal of $\quad$ Econometrics, $\quad 37(2), \quad 195-209$. http://dx.doi.org/10.1016/0304-4076(88)90002-4

\section{Copyrights}

Copyright for this articleis retained by the author(s), with first publication rights granted to the journal.

This is an open-access article distributed under the terms and conditions of the CreativeCommons Attribution license (http://creativecommons.org/licenses/by/3.0/). 